\title{
IIi-Ili: A Local Knowledge of Water Management in Temangung Regency, Central Java
}

\author{
Finariyah Finariyah $^{1 *}$, Noor Naelil Masruroh ${ }^{1}$ \\ ${ }^{1}$ Bachelor Program of History, Faculty of Humanities, Universitas Diponegoro \\ Jl. Prof. Soedarto, S. H., Tembalang, Semarang, Central Java - Indonesia
}

\begin{abstract}
Water is the most important resource for human life. Not only for households, but water also has an important role in agricultural activities. An irrigation system with the local wisdom of the local community is present to support the sustainability of rice fields which has been known for a long time. But today, water is becoming an expensive commodity that is always commercialized. Water has also been a source of conflict in some places. In Temanggung Regency, local people know the existence of $i l i-i l i$, an informal institution that plays a role in regulating the irrigation for rice fields during the dry season. Not only for agricultural rice fields, but ili-ili also regulates the distribution of water to households fairly and without conflict. However, recently no more young people have continued these democratic and fair water management systems. This article uses the historical method, which emphasizes sources analysis and observations. This study proposes a solution to support the continuity of the traditional institution. The local government needs to support by making the water regulators part of the village government so that each community are able to enjoy the water together without causing new conflicts.
\end{abstract}

\section{Introduction}

Throughout their life, humans are always dependent on the nature where they live. One of the resources provided by nature that has humans are addicted to is water. Water is one of human's primary necessities, particularly for drinking. Research shows that $60 \%$ of the human body content is water [1]. In fact, water is not only needed for drinking but also may become an important element in the agricultural farm system. The farm is one form of wetland agriculture that always needs water for its plants' sustainability. The farm is likely to be known far before the Neolithic era after Austronesian speaking people introduced rice to Southeast Asia in diaspora [2]. Along with it, irrigation, as one of the important components of the farm, had also been born. Despite having a long history, only a few researchers were specifically interested in studying the irrigation system. However, some historians had mentioned an old irrigation system, especially in Java, when agrarian politics was intensively carried out during the King Purnawarman era [3].

It is undeniable that water becomes part of a society's identity. In Bali, God Wisnu is personified as the god of water whose existence is very important to farmers [4]. Water

* Corresponding author: ffinariyah@gmail.com 
management cannot be separated from the existence of farms that have led to various cultures for the society where they develop. A water management system is applied pursuant to society's local wisdom. Local wisdom is part of the society regarding how they live their life in adaptation to their living environment in accordance with the needs and beliefs taking root in themselves, making it difficult to get rid of [5]. It is then reasonable that many societies call water management systems and their implementation differently. Basically, those who know the water management system for the farm are people living in an area with fertile soil, and they are commonly living on volcanic mount areas with an abundant source of water from the mountain. One of the famous sources of water in Java is the Progo River, which originates from Umbul Jumprit in Ngadirejo, Temanggung. The water is from Mount Sindoro, which is composed of young volcanic materials, making it able to store water well [6].

Temanggung Regency area also developed agricultural rice land. Although not serving as a granary, the farms still spread widely in Temanggung. The society knows two types of farm management, namely irrigation and rainfed. With regard to farm irrigation management, local society knows $i l i-i l i$, an informal institution assigned to regulate water distribution to farms during the dry season. The working system of ili-ili is also used in domestic water management. However, the size of farms keeps declining from year to year, especially farms with irrigation patterns. In 2016 the area of irrigation farms in Temanggung was 19,788 ha and declined to 19,499 ha in 2018 [7]. One of the reasons of declining irrigation land was the scarcity of water resources during the dry season. Some areas in Temanggung, such as Kandangan and Kaloran were always dry in every dry season, while Temanggung was on a mountain slope that should have been rich in water resources.

The commercialization of water resources was a new issue in Temanggung. Water became an expensive commodity that was difficult to get, especially during the dry season. Society was also required to pay to use it. Farms started to disappear, and the existence of ili$i l i$ was more uncertain. Based on the objective condition, there were two interesting problems in this study, that the water management system in Temanggung is then commercialized and may potentially cause conflict in the society. In addition, the existence of ili-ili as the society's local wisdom in water resource management for irrigation farms in Temanggung Regency is very important to ensure the conservation of the environment and society's needs. To address the research problems, it uses an ecosystem approach that consists of collective local institutional arrangements of water management as well as decision-making processes for water distribution [8].

A study on water resource management based on local wisdom has been conducted by Lubis et al. (2018). The study emphasized the mechanism of the water management system based on local traditional values. As times flies, local values certainly face various challenges. This study shows the urgency of local traditional values to be maintained and preserved. It also provides a contextual description of the implementation of traditional values in the management of water resources today.

\section{Method}

This study employs the historical method, which consists of four stages. It begins with heuristic or collecting historical sources, source criticism or verification, interpretation, and finally historiography or writing history [9]. This study uses some historical sources, including primary and secondary sources. The main information about the existence of ili$i l i$ and their role in water management is explored using oral history. Recently, there are few of ili-ili's generation who still active in their duty due to the absence of young generation in transmitting the knowledge. Result and Discussion. 


\subsection{Geographical and Historical Background}

Temanggung Temanggung Regency is located on land at about 500-1,450 m above sea level. It is astronomically at $110^{\circ} 23^{\prime}-110^{\circ} 46^{\prime} 30^{\prime \prime}$ East Longitude and $7^{\circ} 14^{\prime}-7^{\circ} 32^{\prime} 35^{\prime \prime}$ South Latitude [7]. It is as if Temanggung Regency is on a basin among its surrounding mountains. The relatively famous peaks in Temanggung Regency are Mount Sumbing, Mount Sindoro, and Mount Prau. That the location is not far from mountains benefits local people. Clean air, clean water, and fertile soil are the blessing for the people to be grateful for.

Since the Old Mataram Kingdom era, the Temanggung Regency area has played an important role because this region was close to a holy region, Dihyang, which is currently known as Dieng, located in Wonosobo Regency [10]. Some inscriptions, such as Mantyasih Inscription, tell us that there was a movement of the centre of Old Mataram Kingdom during the leadership of Rakai Panangkaran. The centre of the kingdom was moved along with the change to Rakai Panangkaran's belief in Buddhism. He moved the centre of the kingdom to Kedu region. Maziyah states that there were many holy buildings in the TemanggungParakan region [10]. This is related to the information in Kayumwungan Inscription, which was created in $824 \mathrm{AD}$. The inscription tells many names of sima villages or free-tax villages, such as Waluang in Babadan and Kisir in Kyumwungan. It is then reasonable that in Temanggung region, particularly on the foot of the mountains, many sites of Old Mataram Kingdom heritage were found.

Many sites of Old Mataram Kingdom heritage in Temanggung were found close to the wellspring. For example, Candi Liyangan, a site of the old civilization of Old Mataram Kingdom people in Ngadirejo District. Not far from the location, on the edge of the site, there is a wellspring that is still used by local people until now [6]. There are also the sites Candi Pringapus and Candi Perot in Ngadirejo, not far from Endongsewu spring. From the information, we may observe that important regions during the kingdom era were located not far from the wellspring since water is the most important resource for human life. The people of Old Mataram Kingdom had also known rice farm agriculture which needed a good irrigation system. This may be observed from the finding of agricultural tools and piles of grain scorched by Mount Sindoro eruption about 10-11th C [11]

\subsection{Dynamics of Water Management for Irrigation}

For the sustainability of the farm, the king delegated a special official to regulate it. The new position of Hulu air or irrigation officer arose in society. There were also other official positions closely related to water and farm, such as air warangan (marital water official), matamwak (embankment water official), air haji (royal water official), jukut air (plantation water official), and Hulu wras (rice officer) [2]. Besides assigning new officials who were farm-related, the king also granted tax to land around sima to be made farm. Appanage land was used for dryland agriculture (tgal) and vacant land agriculture (suket) to be made into a farm. Ngabean Inscription of 801 Saka (879 AD) states that raka Kayuwangi asked dry land around Magelang to be made into a farm [3]. Raka only could make such change upon the consent of rama or the local village head as ruler of the appanage land. This also occurred to the slopes of Mounts Sumbing and Sindoro that was given with tax grant to change forest land into farm [2]. During Kediri Kingdom era in East Java, they made irrigation system as contained in Harinjing Inscription of 804 AD [12]. The inscription explains an irrigation system in the farms with canals and embankments. The irrigation system was called dawuhan, receiving water from Harinjing River. Until now, the irrigation system is still used by local society. The system makes the agricultural management quite good with an abundant harvest. 
One of the water management systems that has existed for a long time and is even assigned to be a World Cultural Heritage by UNESCO also exists in Indonesia, particularly Bali. Local society calls it subak as an irrigation system that has existed since the 11th Century [4]. Principally, subak is a farmers' organization assigned to farm management in a certain area. This system is formed based on the philosophy Tri Hita Karana which requires harmony between humans and God. Tri Hita Karana means three paths taken for a happy life. First, harmony between humans and God is referred to as parahyangan. Second, harmony between humans is referred to as pawongan. Lastly, harmony between humans and the environment is referred to as palemahan.

Each society has its respective term, and irrigation systems since basically water management systems are born from local society's wisdom. Local wisdom is part of society related to how their live their life in adaptation to the environment where they are living pursuant to the needs and beliefs taking root in themselves, making it difficult to get rid of [5]. Javanese society knows a tradition named nyadran kali. This tradition is the form of their gratitude for the water available to fulfil their necessities and agricultural activities.

\subsection{Conflict of Water Distribution}

Water Water should become an unlimited natural resource, which is currently an expensive commodity fought over and often causes conflict in society. Human's greed is the main factor of how water in some places becomes an expensive commodity fought over. In the past, the society highly respected water that they even made various traditions as mentioned above, developing with various local wisdom in the society intending to keep clean water available for all people. It is surely different from today that cutting trees down is legalized everywhere, including in protection forests, as long as payment is made by investors. Green area is replaced by concrete roads and skyscrapers, causing water absorption to get reduced. Finally, water commercialization arises. Water is sold by big companies that also take water from mountains. Based on FAO's data, about $69 \%$ of water resources globally used for the agricultural sector decreases to $59 \%$ for agriculture [13].

In the end, farmers currently choose to use the rainfed system to irrigate their farms. Javanese People often call this system pranoto mangsa [14]. They only plant rice in a certain season when water is easily available. Some farmers also choose other systems relying on special technology to irrigate their farms despite spending much cost. Eventually, the traditional irrigation system slowly disappeared because of decreasing irrigation farms. The increasingly modern society surely becomes part of the disappearance of the traditional system. The assumption that anything old must be replaced with the new one is a big mistake.

The traditional water management system also often causes new conflict. For example, the Subak system in Bali has lately caused conflict in society. The utilization of the traditional water management system as one tourist attraction in Bali slowly caused the loss. Water had been exploited excessively for tourism activities, industry, bottled drinking water selling private companies, and regional water delivery services [15]. Tension among people arose from this issue. Paddy also began to lose its popularity. The government's policy of rice imports harmed farmers. Just like recently, when harvest came, the Indonesian government chose to import rice before the fasting months [16]. The government also contributed to farmers' prosperity.

Besides, because of difficult access to water during the dry season, the harvest yield of paddy is not really profitable. Some farmers finally decided to change their farms to the plantation with more profitable commodities. In Temanggung Regency, for instance, farmers preferred planting coffee or tobacco as the city's mainstay commodities. Traditional irrigation farms land started to disappear, replaced by rainfed farms and or replaced by coffee or tobacco plantations. In 2016 the size of irrigation farms in Temanggung was 19,788 ha 
and kept declining to 19,499 ha in 2018 [7]. The millennial generation's disinterest in agricultural activities is also the new reason for the traditional water management system to start disappearing. Farming is not deemed a good job, and some may even deem it an embarrassing job, while it is a fact that they eat the rice from the paddy that the farmers plant. Eventually, local wisdom in the society fades away and disappears. This will eventually be disadvantageous to the society themselves when they must pay more to use water since water is no longer of communal goods that can be used together for free.

\subsection{Local Knowledge in Water Management System in Temanggung}

An appropriate water resource management is still preserved in some places in Temanggung Regency, one of which is in the farms close to Krempong Village, Gemawang District, Temanggung Regency. Local society calls it Alas Krasak, with farms irrigated with water from a small river that they call Malang River. In Alas Krasak, there are farms of local people from Sucen and Ngasinan Villages. They have applied the irrigation system for a long time. Using irrigation systems, their harvest does not depend only on the season. It is different from rainfed farms that only use rainwater to irrigate their farms. Although now, some plots of farms have changed to the plantation to maximize the yield. Some farmers choose to plant chilli on their land that also needs adequate irrigation.

When the dry season comes, the water management in Alas Krasak farms depends on ili-ili. Ili-ili is an individual assigned to be responsible for regulating where water is to be directed to in dry season. In the dry season, the water is relatively limited; thus, the farms are to be irrigated in turn from one to another plot of farms. It is called ili-ili from the Javanese word flowing "mili". Ili-ili itself is those who own farms in the area. For example, if in the area there are farms owned by A and B. On the first day of the dry season, A becomes ili$i l i$ with the obligation to regulate farm irrigation. It is his duty to regulate what time the water should flow to the plot of the farm owned by A and when it is to shift to irrigate the plot of the farm owned by B. On the second day, it is B's turn to be in charge as ili-ili, and so on.

Ili-ili must ensure that each plot of the farm is equally irrigated. He is not paid and works voluntarily for the common interest of having an abundant harvest. With this system, cooperation between those owning farms is greatly needed. One problem in irrigation will affect all farms. Therefore, to solve irrigation problems, all people must participate in and contribute to it. This will only be in the dry season but not in the rainy season since, in the rainy season, each farm will have enough water from the rain. This is just like farms with a rainfed system.

Bamboo trees have been planted around Malang River. This is one of local society's wisdom since bamboo is one type of plant with good water absorption [17]. In the past, the water canal for irrigation was only made of stone and wood, simply adjusted to the soil. Right now, however, the canal has been renewed with concrete on its walls. In the rainy season, water will not flow through this water canal, not because of no water, but the flow of water from Malang River is intentionally stopped since, in the rainy season, the farms only need rainwater that almost fall every afternoon. In the day season, ili-ili or farm owners will jointly make the water from Kali Malang flow again. Local people call it kerja bakti; they work voluntarily without any payment. Besides kerja bakti, local people also know nyadran kali, a tradition of praying and eating together as a form of gratitude for the water that always flows from Malang River. It is thanks to the water that their agricultural activities keep operating despite in dry season. 
Fig. 1. Malang River Irrigation.

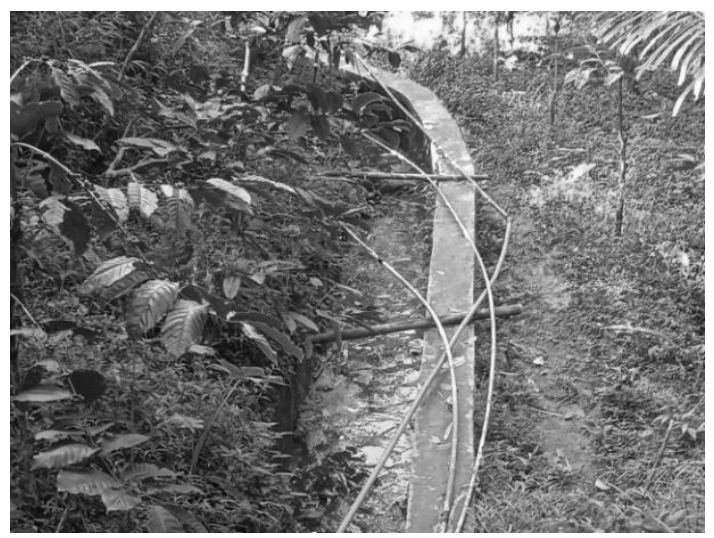

It is not baseless that the irrigation system depending on ili-ili in some areas in Temanggung is still applied. With the existence of $i l i-i l i$, the farmers can at least harvest twice annually since they do not have to rely on someone who manages the harvesting time [pranoto mongso]. One value that is still preserved with the existence of ili-ili is communality. The process of distributing water for farm irrigation greatly depends on ili-ili. Every day, it is certain that ili-ili shifts and they are farm owners. Therefore, the farm owners must always cooperate to perform their duties as ili-ili when it is their schedule to take charge. They must also mutually cooperate in case of a problem in their irrigation system since even only one problem in the irrigation system can lead to the failure of all of the plots of the farm. Mutual cooperation builds souls that prioritize joint value to personal interest. Through mutual cooperation, social solidarity can be established well among the society. With the existence of $i l i-i l i$, water is common property. Water is part of the social dimension that must be useful to everyone. Each party has the right to water without exception, instead of only a few people who can afford to pay. Just like it is now, some people choose to use the company's service, such as PDAM. In this case, water is part of the economic dimension, while it is a natural resource that can be used to fulfil people's life necessities. Each of the people has the right to utilization of water appropriately. Water should not be commercialized, becoming part of sale and purchase for personal benefit.

Ili-ili also ensures the sense of ownership of a communal resource. "Water is a common property" becomes part of the concept of common property resources [14]. In this sense, everyone in society has the same responsibility to keep water sustainable. Society will ensure that water will remain their property. There is no commercialization by an external party to allow water to become a commercialized item. This sense will also ensure that the existing local wisdom will be preserved in the society's life as long as they exist and apply the iliili system. Basically, any local wisdom is very useful to the society it belongs to. Ili-ili is not only useful for harvest profit but also to keep nature balanced. It ensures water keeps flowing and be used together. Therefore, local wisdom should always be preserved by society. When local wisdom fades away, society's condition will also shift. Local wisdom is part of the society that must always be preserved. 


\section{Conclusion}

Up until now, water is still the most important resource to humans, that they cannot survive without it. Water plays an important role in natural balance and human life. Water, which is part of renewable natural resources because of its unlimited amount, is currently the source of new problems. Water shortage occurs in many places, causing the new culture of water resource commercialization. Meanwhile, each society, the rich and the poor, those in rural and urban areas, all need water to support their interests. In rural areas serving as a granary, water is an important resource that the farmers need for their farm management, that without it, their farm cannot operate appropriately.

Ili-ili is part of the society in the Temanggung region who is responsible for the flow of water onto each farm, especially in the dry season. Ili-ili is the form of the society's local wisdom in the management of water resources to fulfil their common necessities. Ili-ili is not paid, but they voluntarily perform their duties. This is the case since society knows well that water is a communal resource and belongs to all people instead of only personal property. They must cooperate to utilize the water as well as possible for mutual benefit. In this case, ili-ili plays a very important role in the life of rice granary society. It will surely be better if $i l i-i l i$ becomes part of local government, with an expectation that their existence will be preserved and water will still be used together without causing conflict.

Local wisdom contains positive values to society. This is one of the reasons why local wisdom must be preserved. In the case of $i l i-i l i$, the society gains the benefit of using water together for free. It is also with this system that they will be united and have higher solidarity, making them live in harmony without conflict regarding the utilization of water resources.

The author would like to thank Faculty of Humanities Universitas Diponegoro, for funding this publication and give us chance to disseminate our research.

\section{References}

[1] D. M. Hartono, Sistem Penyediaan Air Minum dan Permasalahannya, Univ. Indones., (2014)

[2] J. W. Christie, Water and rice in early Java and, World Water, 235-258 (2013)

[3] D. Lombard, Nusa Jawa: Silang Budaya, Warisan Kerajaan-kerajaan Konsentris, (2005)

[4] W. Windia, S. Sumiyati, G. Sedana, Aspek Ritual pada Sistem Irigasi Subak sebagai Warisan Budaya Dunia, J. Kaji. Bali J. Bali Stud., 5, 23-56 (2015)

[5] R. Sufia, Sumarmi, A. Amirudin, Kearifan Lokal Dalam Melestarikan Lingkungan Hidup (Studi Kasus Masyarakat Adat Desa Kemiren Kecamatan Glagah Kabupaten Banyuwangi, J. Pendidik. Teori Penelit. Dan Pengemb., 1, 726-731 (2016)

[6] A. Ashari, Distribusi Spatial Mataair Kaitannya dengan Keberadaan Situs Arkeologi di Kaki Lereng Gunungapi Sindoro Antara Parakan dan Ngadirejo Kabupaten Temanggung, 169-179 (2014)

[7] B. K. Temanggung, Kabupaten Temanggung dalam Angka 2018, (BPS Kabupaten Temanggung Temanggung, 2018)

[8] Biosafety Unit, (May, 2021), Ecosystem Approach, Retrieved from https://www.cbd.int/ecosystem/

[9] Wasino, E. Sri, Metode Penelitian Sejarah, 2nd ed., (Magnum Pustaka Utama Yogyakarta, 2018)

[10] S. Maziyah, Kondisi Jawa Tengah Pada Abad VIII Sampai Abad XV M 
[11] S. Riyanto, Liyangan: Kini, Doeloe, dan Esok, (Balai Arkeologi Daerah Istimewa Yogyakarta, 2016)

[12] I. Kurnia, Mengungkap Nilai-Nilai Kearifan Lokal Kediri Sebagai Upaya Pelestarian Budaya Bangsa Indonesia, J. PGSD, 11, 51-63 (2018)

[13] H. Rahman, S. Yusman, M. P. Hutagaol, M. Firdaus, Deskripsi Komparatif Iuran Pengelolaan Irigasi (IPI) di Saluran Induk Daerah Irigasi Jatiluhur Jawa Barat, J. Sos. Ekon. Dan Kebijak. Pertan., 7, 176-187 (2018)

[14] D. Hidayati, Memudarnya Nilai Kearifan Lokal Masyarakat Dalam Pengelolaan Sumber Daya Air, J. Kependud. Indones., 11, 39-48 (2016)

[15] S. Strauß, Water Conflicts among Different User Groups in South Bali, Indonesia, Hum. Ecol., 39, 69-79 (2011)

[16] CNN Indonesia, Pemerintah Mau Impor Beras, Petani Menjerit, (2021)

[17] M. R. Lubis, H. Kaskoyo, S. B. Yuwono, C. Wulandari, Kearifan Lokal dalam Pengelolaan Mata Air di Desa Sungai Langka, Kecamatan Gedong Tataan, Kabupaten Pesawaran, Provinsi Lampung, J. Hutan Trop., 6, 90 (2018) 